\title{
Glomalin and Contribution of Glomalin to Carbon Sequestration in Soil: A Review
}

\author{
Mohammed Belal Hossain ${ }^{1, a, *}$ \\ ${ }^{1}$ Soil Science Division, Bangladesh Institute of Nuclear Agriculture (BINA), Bangladesh Agricultural University campus, Mymensingh \\ 2202, Bangladesh \\ *Corresponding author
}

A R T I C L E I N F O A B S T R A C T

Review Article

Received : 11/08/2020

Accepted : 09/10/2020

Arbuscular mycorrhizal fungi (AMF) improves the uptake of nutrients and water to the plants through mutual symbiosis. Only AMF produces glomalin related soil protein (GRSP). Acaulospora morroaiae, Glomus luteum, Glomus verruculosum, Glomus versiforme are the effective glomalin producing AMFs. Mixed primary forest, tropical rainforest, soil organic matter, clay soil, no tillage, quality and quantity of fertilizers, crop rotation, and water stable aggregates are also suitable to increase glomalin production. Glomalin is a glycoprotein that contains $30-40 \%$ carbon (C) which is assumed to be stable and persistent in soil. The glomalin can sequestrate more carbon in the soil due to its high carbon and aggregate stability. Greater aggregate stability leads to high organic carbon protection in terrestrial ecosystems. The lowest glomalin content ( $0.007 \mathrm{mg}$ per gram soil) was found in Antarctic region, and the highest glomalin content $(13.50 \mathrm{mg}$ per gram soil) was

Keywords:

Mycorrhizal fungi species Glomalin Glomalin carbon pools Soil aggregate formation Carbon sequestration observed in tropical rainforest. In agricultural soil, glomalin content varies between 0.30 and 0.70 mg per gram soil. The GRSP containing soil organic carbon (SOC) in deeper soil layers was 1.34 to 1.50 times higher than in surface layers. Glomalin can sequestrate $0.24 \mathrm{Mg} \mathrm{C}^{-1}$ in soil when present at $1.10 \pm 0.04 \mathrm{mg} \mathrm{g}^{-1}$. At elevated $\mathrm{CO}_{2}\left(700 \mu \mathrm{mol} \mathrm{mol}^{-1}\right)$ level, easily extractable glomalin (EEG) and total glomalin (TG) were 2.76 and $5.67 \%$ SOC in the surface soil layer over ambient carbon dioxide $\left(\mathrm{CO}_{2}\right)$ level. This finding indicates the effective function of GRSP C sequestration in soil under global environmental change scenarios. Glomalin can also protect labile carbon that can help regulating nutrient supply to the plants. No tillage practice causes higher AMF hyphal length, GRSP and water stable aggregate (WSA) compared to that of conventional tillage practice. The current review demonstrated that GRSP is an important tool for carbon storage in deep soils. Glomalin mediates soil aggregates, improves soil quality, increases carbon sequestration and crop production, and mitigates climate change.

belalbina@gmail.com

(iD) http://orcid.org/0000-0003-3480-718X|

This work is licensed under Creative Commons Attribution 4.0 International License

\section{Introduction}

Soil organic matter (SOM) improves soil and air quality through increasing agricultural production and improving environmental functions. The SOM also affects the dynamics and bioavailability of plant nutrients, infiltration rate, available water capacity, and the resistance against erosion by water and wind. Sequestrated carbons in the soil are used in agriculture, forestry, and reduce ever increased carbon dioxide from the atmosphere (Batjes 1996; Del Galdo et al., 2003; Lal, 2003). There are many ways such as conservation agriculture, minimum or zero tillage, and use of living or dead organic materials to increase SOC in soil. Since 1996 some researchers claimed that AMF mediated glomalin directly as well as indirectly can sequestrate carbon in the soil. Glomalin owns a plentiful amount of insoluble hydrophobic glycoprotein, which can protect the decomposition of soil organic matter. The GRSP is considered an essential component of the SOC pool in terrestrial ecosystems (Jia et al., 2016). Understanding the mechanism for controlling the accumulation and stability of soil $\mathrm{C}$ is critical to predict the future climate of the earth (Knorr et al., 2005). A recent study shows AMF can only produce copious amounts of insoluble, hydrophobic, recalcitrant glycoprotein, named glomalin. Stable aggregates can store and protect the SOC until the aggregates break down. Protected organic carbons increase with the increase of aggregate stability in soil. Very little information is available regarding glomalin content by different factors and the effect of glomalin on soil quality and crop productivity through sequestration of $\mathrm{C}$ and mitigation of climate change. Therefore, this review discusses the effect of different factors on glomalin content and direct and indirect impacts of glomalin on $\mathrm{C}$ sequestration in soils, soil health, crop production and climate change. 


\section{Materials and Methods}

This review is based on the use of secondary data from different journals, research magazines, scientific reports, books, and proceedings. The review focused primarily on the literature search and restricted to articles and report papers published. The published articles were searched and identified from different electronic databases, author's research article, Web of Science, International system for agricultural science and technology (AGRIS), Research Gate, Science Direct, and Springer. The documents collected were mainly focused on glomalin and the effect of glomalin on soil aggregates and $\mathrm{C}$ dynamics in soil and plants. For a critical review, data and literature were compiled and discussed on the effect of AMF species, factors affecting on the glomalin content, carbon pool in glomalin, soil aggregate formation by glomalin, direct and indirect effect of glomalin for carbon sequestration in soil and plant to mitigate the climate change. Using these criteria, 53 studies were found suitable to be included in the review (see references of review). I also complemented this search with references cited in the primary literature. These studies were published over 26 years between 1994 and 2020 .

\section{Results and Discussion}

Factors Affecting Glomalin Content and the Effect of Glomalin on Soil Characteristics

Plant root provides $\mathrm{C}$ for growth and reproduction of a ubiquitous group of symbiotic fungi called AMF. Only AMF produces GRSP. The GRSP contains $2.35-2.56$ times higher in the primary forest than the secondary forest and farmlands (Wang et al., 2015). Different AMF species produce different amounts of glomalin. Among the studied AMF species Acaulospora morroaiae, Glomus luteum, Glomus verruculosum, Glomus versiforme produced significant amount of glomalin (Wright et al., 1996). Similar findings were reported by Wright and Upadhyaya (1999). Acaulospora morroaiae and Glomus intraradices AMF produced the highest and the lowest glomalin contents among the studied Acaulospora morrowiae, Gigaspora rosea, Glomus etunicatum, and Glomus intraradices AMF (Lovelock et al., 2004). Management practices such as tillage, quantity, and quality of fertilizers applied, over-grazing, and plant protection strategies impact on AMF viability and community structure (Oehl et al., 2004; Jarecki and Lal, 2005). Wright and Upadhyaya (1998) conducted research in cultivated and undisturbed soils observed that aggregate stability and immune reactive easily extractable glomalin (IREEG) fraction increased in undisturbed soil. Nichols and Wright (2005) reported that native grasses soil contained higher amounts of glomalin than introduced grasses soil as well as after shifted these lands to cattle, glomalin content was higher than overgrazed soils. The GRSP structures and their differences depend on the content of SOC as well as the depth of soil (Wang et al., 2020). Different pools of glomalin such as TG, immune reactive total glomalin (IRTG), EEG, and IREEG directly contribute carbon sequestration in soil (Figure 1). In respect of TG, the decline rate was observed 16.65 and $46.04 \%$ in fallow land, and the arable land systems compared to forest land, respectively. On the other hand, EEG is positively correlated with the amount of $\mathrm{C}$ and $\mathrm{N}$ in soil. It means the EEG increases with the increase of $\mathrm{C}$ and $\mathrm{N}$ in soil (Fokrom et al., 2013). Wang et al. (2015) also reported that GRSP content is positively correlated with SOC irrespective of the detailed descriptions of surface and deep soils. Glomalin decreased with the increase of soil depth, and the ration of glomalin to SOC was $1.34-1.50$ times higher in $80-100 \mathrm{~cm}$ depth than 0$20 \mathrm{~cm}$ depth (Wang et al., 2017). The highest SOC and EEG (36.8 and 0.53) were observed in forest land use, whereas the maximum TG was observed in horticultural land management systems at $0-15 \mathrm{~cm}$ soil depth (Figure 2). At $15-30 \mathrm{~cm}$ soil depth, the maximum SOC, TG, and EEG (3.62, 4.47, and 0.35$)$ were obtained from the forest land use system. The findings show that SOC decreased with the increase of soil depth as well as forest soil always the highest results in respect of SOC, TG, and EEG except in TG up to $15 \mathrm{~cm}$ soil depth. Wang et al. (2020) also reported that AMF produced 1.8-2.0 times higher GRSP up to 40 $\mathrm{cm}$ soil layer than at $40-100 \mathrm{~cm}$. GRSP related SOC sequestrated 1.2 times higher in deep soil than surface soil.

Factors affecting glomalin contents in soil

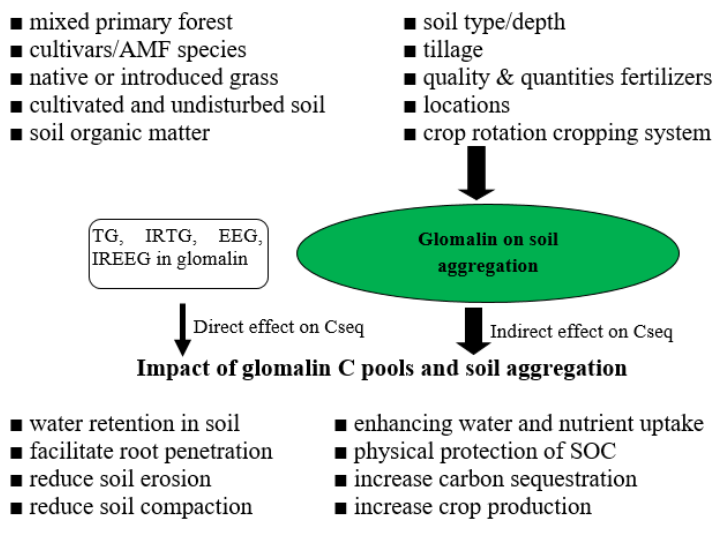

Figure 1. Factors affecting the glomalin and soil aggregation

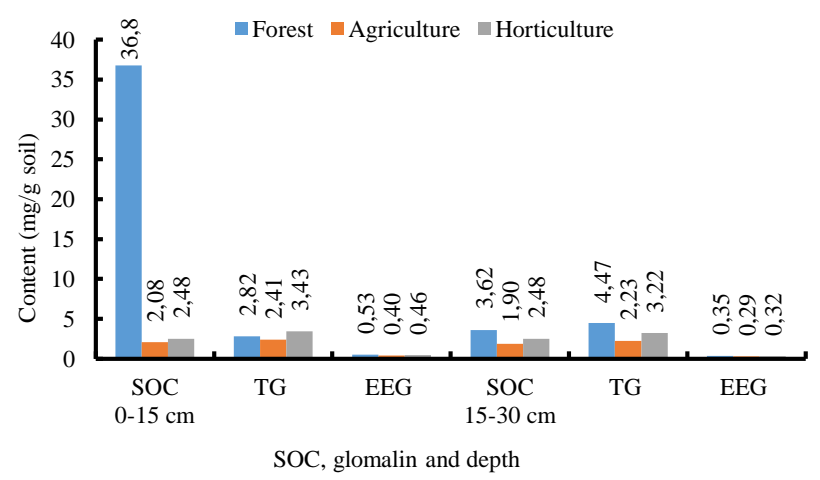

Figure 2. Soil organic carbon (SOC), total glomalin (TG) and easily extractable glomalin (EEG) in two soil depths of the three land use types (adapted from Nautiyal et al., 2019)

The AMF biomass decreased with the increase of soil depth under soybean-soybean rotation, and it increased more than $50 \%$ biomass at below $35 \mathrm{~cm}$ soil depth (Higo et al., 2013). Japanese winter wheat cultivars produce significant amount of extra radical hyphal biomass due to the penetration more than one meter of the soil depth 
(Araki and Iijima, 2001). In respect glomalin amount, the correlation between soil and in vitro culture was negatively correlated due to the difference of hyphal length under fertile, non-fertile soils, and soil aggregates (Rillig and Steinberg, 2002; Lovelock et al., 2004). More carbon can store in $1 \mathrm{~m}$ depth to help carbon sequestration in soil. The content of SOC and the aggregate stability also impacted on the glomalin concentration in arable soils because it significantly functioned on SOM content, biological activity, and nutrient cycling in the soil (Wang et al., 2018; Bedini et al., 2009; Curaqueo et al., 2010; Sharif et al., 2018). Land use systems such as cultivation and fallow practices decreased the glomalin content in soil due to land use practices hampered the growth of AMF. The AMF biomass such as spores, extra radical hyphae, and colonized root segments is contributed to the cropping system performance. The GRSP is a glycoprotein produced by the hyphae of AMF that contains large contents of metal ions (Wright et al., 1996). The AMF mediated glycoproteins contain significant amount of metal ions (Wright et al., 1996). Glomalin content results are presented in the Table 1, and the extent is $0.007-13.50 \mathrm{mg}$ per gram soil in the different environments. The highest glomalin content was found in tropical rainforest (13.50 $\left.\mathrm{mg} \mathrm{g}^{-1}\right)$, and the lowest glomalin content was observed in desert soil in the world. Glomalin can sequestrate $0.24 \mathrm{Mg}$ $\mathrm{C} \mathrm{ha}^{-1}$ in soil when present at $1.10 \pm 0.04 \mathrm{mg} \mathrm{g}^{-1}$ (Wang et al., 2018). It is estimated that AMF contributes $0.24 \mathrm{Mg} \mathrm{C}$ $\mathrm{ha}^{-1}$ when glomalin content is $1.10 \pm 0.04 \mathrm{mg} \mathrm{g}^{-1}$ soil (Wang et al., 2018).

Table 1. Glomalin in various environment

\begin{tabular}{|c|c|c|}
\hline Environment & Glomalin & References \\
\hline Agricultural land & $0.3-0.7 \mathrm{mg} \mathrm{g}^{-1}$ & Wright and Anderson, 2000; Wuest et al., 2005 \\
\hline Boreal forest & $1.10 \mathrm{mg} \mathrm{g}^{-1}$ & Treseder et al., 2004 \\
\hline Desert & $0.003-0.13 \mathrm{mg} \mathrm{g}^{-1}$ & Rillig et al., 2003; Tresedder and Turner, 2007 \\
\hline Temperate forest & $0.60-5.80 \mathrm{mg} \mathrm{g}^{-1}$ & $\begin{array}{l}\text { Steinberg and Rillig, 2003; Nicholas and Wright, } \\
2005 \text { Treseder and Turner, } 2007\end{array}$ \\
\hline Temperate grassland & $0.23-2.50 \mathrm{mg} \mathrm{g}^{-1}$ & $\begin{array}{l}\text { Lutgen et al., 2003; Batten et al., 2005; Nicholas } \\
\text { and Wright, } 2005\end{array}$ \\
\hline Tropical rainforest & $2.60-13.50 \mathrm{mg} \mathrm{g}^{-1}$ & Lovelock et al., 2004; Treseder and Turner, 2007 \\
\hline Antarctic region & $0.007-0.15 \mathrm{mg} \mathrm{g}^{-1}$ & Pohanka and Vleck, 2018 \\
\hline $\begin{array}{l}\text { Marine sediments }(0-10 \mathrm{~cm}) \\
\text { (Yellow river delta) }\end{array}$ & $1.10 \pm 0.04 \mathrm{mg} \mathrm{g}^{-1}\left(0.24 \mathrm{Mg} \mathrm{Cha}^{-1}\right)$ & Wang et al., 2018 \\
\hline $\begin{array}{l}\text { Planted pine forest, } \\
\text { secondary mixed pine and } \\
\text { broadleaf forest }\end{array}$ & $\begin{array}{l}2.63 \pm 0.37,4.22 \pm 0.31 \text { and } \\
4.99 \pm 0.57 \mathrm{mg} \mathrm{g}^{-1}, \text { respectively }\end{array}$ & Zhang et al., 2016 \\
\hline Tropical soil & $60 \mathrm{mg} \mathrm{cm}^{-3}$ & Rillig et al., 2001 \\
\hline Hawain soils & $>100 \mathrm{mg} \mathrm{g}^{-1}$ & Rillig et al., 2001 \\
\hline Arid soil & $<1 \mathrm{mg} \mathrm{g}^{-1}$ & Rillig et al., 2001 \\
\hline Prairie soil & $28-45 \% \mathrm{C}$ & Huang et al., 2011 \\
\hline
\end{tabular}

\section{Effects of Glomalin on Soil Aggregate Formation}

Soil aggregates are composed of primary particles, which are strongly attached to each other in soil aggregation. Primary particles and clay microstructure, decomposable organic matter, fungal hyphae, and plant debris, small roots, and glomalin are the important components of soil aggregates. According to the concept I, larger micro-aggregates are formed with the combination of soil particles, fungal, and plant debris such as organic matter and so on. Micro-aggregates turn into macroaggregates (> $250 \mu \mathrm{m}$ in diameter) through the binding agents of decomposable organic materials and small diameter roots and associated AMF hyphae (Miller and Jastrow, 2000; Rillig and Mummey, 2006) (Figure 3). Hoorman et al. (2011) explained that three steps are followed for the formation of soil aggregation by the hyphal of AMF. The physical process is helped to form macro -aggregates with the combination of Hyphae of AMF and the soil particles. Second, in micro-aggregates of soil, fungi physically protect the clay and organic particles of before said micro-aggregates. Third, glomalin is produced by the plant root and fungal hyphae, which helped to combine glues micro-aggregates, and smaller macro-aggregates together turn into larger macroaggregates. In concept II, recent research findings revealed that AMF hyphal containing glycoprotein act glue to bind dispersed soil particles and other materials such as organic debris of the soil (Figure 3). Soil aggregation conducts the physical protection of SOC within aggregates to inhibit the microbial activity on SOC in soil (Amado et al., 2006). Further degradation of soil aggregation, it stores and protects the additional organic carbon in the soil. An amount of glomalin and the aggregate stability are closely correlated to the indirect effect of SOC storage in the soil (Wright et al., 2000; Rillig et al., 2001; Rillig, 2004; Wright and Nichols, 2002). Stable soil aggregates increased the storage of SOC by the inhibition of microbial activity (Rillig, 2004; Rillig et al., 2007). The IREEG pool is an important factor for soil aggregate stability irrespective of soil types and locations. IREEG is similar to glomalin in AMF hyphae through the use of analytical procedures (Wright and Upadhyaya, 1998). Filamentous structures of AMF mediated hyphae helped to stabilize the aggregation of soil. The AMF is responsible for the formation of macro-aggregates of soils is well documented by the different researchers (Wright and Anderson, 2000; Rillig et al., 2002). Glomalin abundant in soils also closely correlated with aggregate water-stability. Glomalin contributes an insignificant amount of carbon compared to the terrestrial carbon pool, but the glomalin mediated soil aggregation protects from the degradation of carbonaceous compounds inside the aggregates. 


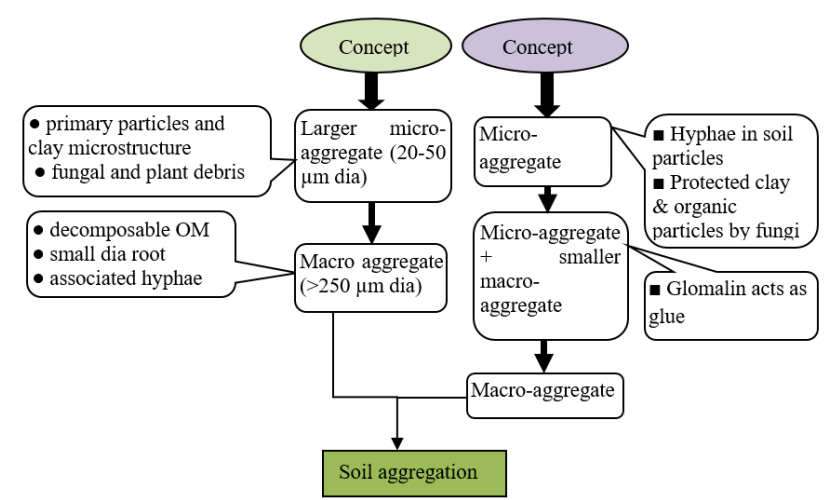

Figure 3. Concept of soil aggregation process by glomalin of AMF

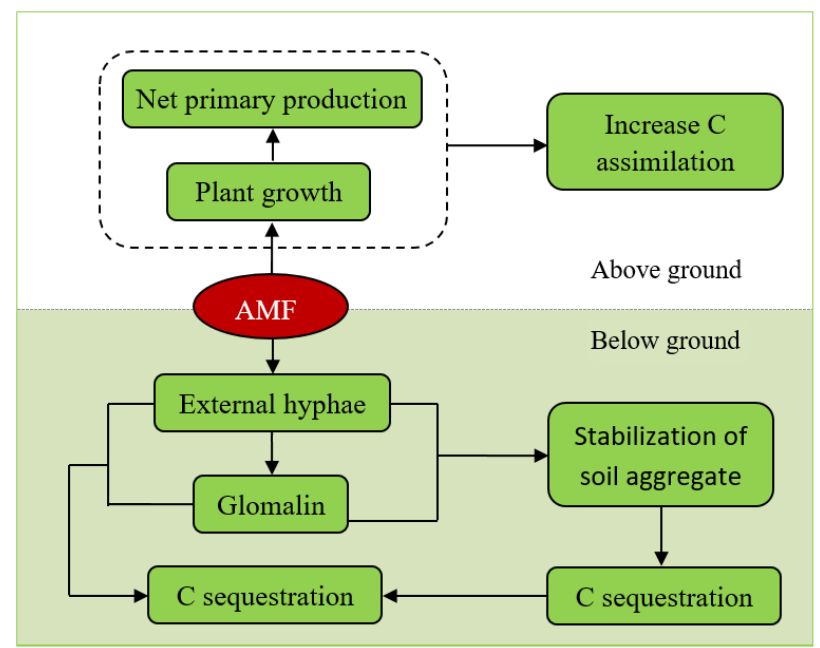

Figure 4. Regulation of carbon fluxes between biosphere and atmosphere by AMF (adapted from Zhu and Miller, 2003)

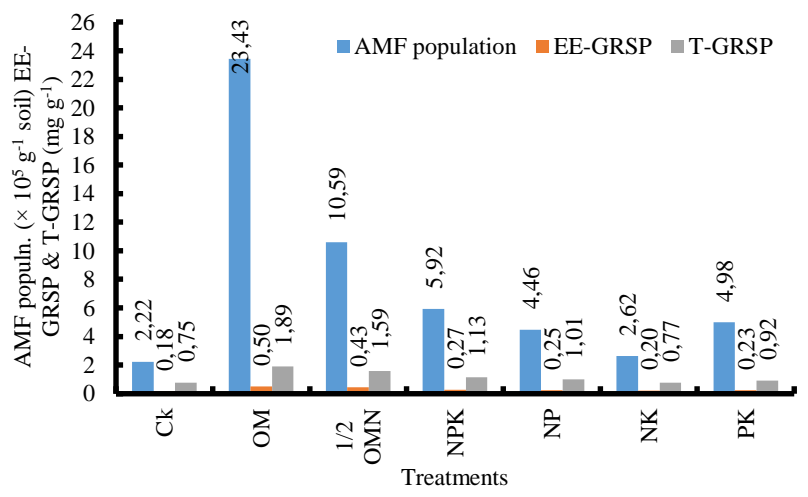

Figure 5. Effect of different fertilizer practices on AMF population and glomalin proteins

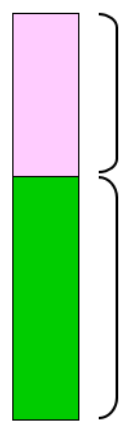

$0-40 \mathrm{~cm}$ soil depth

- GRSP increase with decrease soil depth

- protect labile carbon by GRSP

- increase carbon stock in soil

$40-100 \mathrm{~cm}$ soil depth

- GRSP/SOC increase with increase soil depth

- carbon flux decrease due to lack of oxygen

- reduce carbon dioxide level in atmosphere

- mitigate climate change

Figure 6. Impact of glomalin on different depths of soil
A sticky net is produced by AMF mediated hyphae and glomalin that pitfalls primary soil particles such as sand, silt, clay, and organic matter in the soil. Hyphae and glomalin together form a sticky net that traps particles of sand, silt, clay, organic matter and holds them together to create a lump or aggregate of the soil.

Effect of Soil Aggregates on Carbon Sequestration and Crop Production

Labile carbon is protected in glomalin mediated soil aggregates (Liu et al., 2020). The GRSP variations in respect of the ratio of SOC, total nutrients, and TG display different depths of soil. The GRSP contributes significant amount of organic carbon storage and nutrient levels in deeper soil than surface soil in respect of GRSP/SOC ration. Curaqueo et al. (2010) reported that the significant relationship happened between GRSP and water stable aggregate in the soil. Conservation practice such as minimum tillage improved the significant AMF hyphal length, glomalin related soil protein, and water stable aggregates over traditional tillage practice (Curaqueo et al., 2010). No or minimum tillage increases of $44 \%$ total organic carbon in soil compared to conventional tillage. Micro-aggregates contain old organic carbon, and younger organic carbon stays in micr-aggregates in soil. Carbon sequestration efficiency is higher in upland soils than in paddy soils irrespective of all aggregates sizes in the same climatic condition and from the same parent material. The SOC ranges from 89.40 to $95.10 \%$ in different physical fractionations of soil. The amount of $\mathrm{CO}_{2}$ levels depends on aggregate size, water stable aggregates, and glomalin under sandstone and serpentine media (Wright et al., 2000). Ambient and enriched $\mathrm{CO}_{2}$ levels in serpentine increased the glomalin content compared to sandstone with ambient and enriched $\mathrm{CO}_{2}$ levels. The WSA improved in sandstone with ambient and enriched $\mathrm{CO}_{2}$ level compared to serpentine with ambient and enriched $\mathrm{CO}_{2}$ level. This finding is concluded that the significant amount of aggregates improves water stabile aggregates in sandstone. The AMF and plant roots symbiosis promote the absorption of nutrients and water to plants in different ecosystems (Figure 4). The AMF improves soil physical properties that can progress the aggregation of soil. Keeling et al. (1995) discussed that efforts should explore to sequester ever increasing $\mathrm{CO}_{2}$ in terrestrial ecosystems. Green parts of the plant apprehend $\mathrm{CO}_{2}$ from the atmosphere and redistribute the plant mediated photosynthate to roots and into the soil through root exudates (Rogers et al., 1994). Enrichment of atmospheric $\mathrm{CO}_{2}$ increases glomalin production due to improves the symbiosis between glomalin mediated AMF and plant roots. At elevated $\mathrm{CO}_{2}\left(700 \mu \mathrm{mol} \mathrm{mol}{ }^{-1}\right)$ level, EEG and TG increased 2.76 and $5.67 \%$ SOC in the surface soil layer over ambient $\mathrm{CO}_{2}$ level in heavy metal contaminated soil. The GRSP also improves the rhizosphere SOC under elevated $\mathrm{CO}_{2}$ level and heavy metal contaminated soil. Pools of glomalin such as easily extractable and TG related protein increase in elevated $\mathrm{CO}_{2}$ level under improved symbiosis between AMF and Robinia pseudoacacia seedlings (Vodnik et al., 2008). Dai et al. (2013) reported that organic manure and mineral fertilizers and their different combinations produced the highest AMF population, EE-GRSP and TG-GRSP over control 
treatment under winter wheat, and summer maize rotation (Figure 5). Kalam et al. (2011) reported that the maximum grain yield of rice $\left(4.45 \mathrm{tha}^{-1}\right)$ was observed in $\mathrm{N}_{200} \mathrm{P}_{40}+$ vesicular arbuscular mycorrhiza (VAM), which was statistically similar to $\mathrm{N}_{200} \mathrm{P}_{20}+$ VAM treatment. Plant biomass and photosynthesis product allocation control the amount of glomalin production in soil. Plant gets sufficient amount of available nutrients by AMF symbiosis process in nutrient deficient soil. Photosynthetically plants supply carbon to AMF, which controls glomalin production by AMF (Treseder and Allen, 2000). The application of VAM inoculum may be stimulated growth and yield of rice as compared to un-inoculated rice plant. Maximum GRSP content was found in surface soil, but the maximum GRSP/SOC content was observed in 40-100 cm soil depth (Figure 6).

\section{Conclusion}

The AMF mediated process involved in the storage of $\mathrm{C}$ in soils is the transfer of photosynthate from host plants to AMF hyphae. Effective AMF was identified for increasing glomalin concentration in soil. The highest GRSP content was recorded in surface soil, but the maximum GRSP/SOC content was observed in 40-100 cm soil depth. Glomalin is a carbohydrate associated glycoprotein and contains $30-40 \%(w / w) ~ C$ which is assumed stable, and persistent in soil, and is thought to be produced in copious quantities by AMF. The results of this review revealed that glomalin improves soil quality as well as help mitigating the global climate change.

\section{References}

Amado TJC, Bayer C, Conceiqdo PC, Spagnollo E, de Campos BHC, da Veiga M. 2006. Potential of carbon accumulation in no-till soils with intensive use and cover crops in Southern Brazil. J. Environ. Qual., 35: 1599-1607.

Araki H, Iijima M. 2001. Deep rooting in winter wheat: rooting nodes of deep roots in two cultivars with deep and shallow root systems. Plant Prod. Sci., 4: 215-219.

Batjes NH. 1996. The total carbon and nitrogen in the soils of the world. European J. Soil Sci., 47: 151-163.

Batten KM, Six J, Scow KM, Rillig MC. 2005. Plant invasion of native grassland on serpentine soils has no major effects upon selected physical and biological properties. Soil Biol. Biochem., 37: 2277-2282.

Bedini S, Pellegrino E, Avio L, Pellegrini S, Bazzoffi P, Argese E, Giovannetti M. 2009. Changes in soil aggregation and glomalin-related soil protein content as affected by the arbuscular mycorrhizal fungal species Glomus mosseae and Glomus intraradices Soil Biol. Biochem., 41: 1491-1496.

Curaqueo G, Acevedo E, Cornejo P, Seguel A. 2010. Tillage effect on soil organic matter, mycorrhizal hyphae and aggregates in a Mediterranean agro-ecosystem. J. Soil Sci. Plant Nutr., 10(1): 12-21.

Dai J, Hu J, Lin X, Yang A, Wang R, Zhang J, Wong MH. 2013. Arbuscular mycorrhizal fungal diversity, external mycelium length, and glomalin-related soil protein content in response to long-term fertilizer management. Journal Soils Sediments, 13:1-11.

Del Galdo I, Six J, Peressotti A, Cotrufo MF. 2003. Assessing the impact of land-use change on soil $\mathrm{C}$ sequestration in agricultural soils by means of organic matter fractionation and stable C isotopes. Global Change Biol., 9: 204-1213.
Fokom R, Teugwa MC, Nana WL, Ngonkeu MEL, Tchameni S, Nwaga D, Rillig CM, Amvam ZPH. 2013. Glomalin, carbon, nitrogen and soil aggregate stability as affected by land use changes in the humid forest zone in South Cameroon. Appl. Ecol. Environ. Res., 11(4): 581-592.

Higo M, Isobe K, Yamaguchi M, Drijber RA, Jeske ES, Ishii R. 2013. Diversity and vertical distribution of indigenous arbuscular mycorrhizal fungi under two soybean rotational systems. Biol. Fert. Soils, 49(8): 1-12.

Hoorman JJ, de Moraes Sa JC, Reader R. 2011. The biology of soil compaction. American Society of Agronomy. Crops Soils Magazine, pp. 4 - 10.

Huang Y, Wang DW, Cai JL, Zheng WS. 2011. Review of glomalin-related soil protein and its environmental function in the rhizosphere. Chinese J. Plant Ecol., 35: 232-236.

Jarecki MK, Lal R. 2005. Soil organic carbon sequestration rates in two long-term no-till experiments in Ohio. Soil Sci., 170: 280-291.

Jia X, Zhao YH, Liu T, Huang SP, Chang YF. 2016. Elevated $\mathrm{CO}_{2}$ increases glomalin-related soil protein (GRSP) in the rhizosphere of Robinia pseudoacacia L. seedlings in $\mathrm{Pb}$-and Cd-contaminated soils. Environ. Poll., 218: 349-357.

Kalam MA, Hossain MB, Sarmin T, Moslehuddin AZM, Khan MMK. 2011. Different levels of nitrogen and phosphorus with or absence of VAM fungal inoculum on rice (Oryza sativa L.). J. Agrofor. Environ., 5(2): 7-10.

Keeling CD, Whorf TP, Wahlen M, Van der Plicht J. 1995. Interannual extremes in the rate of rise of atmospheric carbon dioxide since 1980. Nature, 375: 666-670.

Knorr W, Prentice IC, House JI, Holland EA. 2005. Long-term sensitivity of soil carbon turnover to warming. Nature, 433: 298-301.

Lal R. 2003. Global potential of soil carbon sequestration to mitigate the greenhouse effect. Critical Reviews Plant Sci., 22: 151-184.

Liu H, Wang X, Liang C, Ai Z, Wu Y, Xu H, Xue S, Liu G. 2020. Glomalin related soil protein affects soil aggregation and recovery of soil nutrient following natural revegetation on the Loess Plateau. Geoderma, 357: 1-11.

Lovelock CE, Wright SF, Clark DA, Ruess RW. 2004. Soil stocks of glomalin produced by arbuscular mycorrhizal fungi across a tropical rain forest landscape. J. Ecol., 92: 278-287.

Lutgen ER, Muir-Clairmont D, Graham J, Rillig MC. 2003. Seasonality of arbuscular mycorrhizal hyphae and glomalin in a western Montana grassland. Plant Soil, 257: 71-83.

Miller RM, Jastrow JD. 2000. Mycorrhizal fungi influence soil structure. In: Arbuscular Mycorrhizas: Physiology and Function (eds.) Kapulnik Y, Douds DD, Jr). Kluwer Academic Publishers, the Netherlands. pp. 3-18.

Nichols KA, Wright SF. 2005. Comparison of glomalin and humic acid in eight native US soils. Soil Sci., 170: 985-997.

Oehl F, Sieverding E, Mader P, Dubois D. 2004. Impact of longterm conventional and organic farming on the diversity of arbuscular mycorrhizal fungi. Oecologia, 138(4): 574-583.

Pohanka M, Vlcek V. 2018. Assay of glomalin using a quartz crystal microbalance biosensor. Electroanalysis, 30: 453458.

Rillig MC, Wright SF, Nichols KA, Schmidt WF, Torn MS. 2001. Large contribution of arbuscular mycorrhizal fungi to soil carbon pools in tropical rain forest. Plant Soil 233: 167-177.

Rillig, MC, Wright SF, Eviner VT. 2002. The role of arbuscular fungi and glomalin in soil aggregation: comparing effects of five plant species. Plant Soil, 238: 325-333.

Rillig MC, Steinberg PD. 2002. Glomalin production by an arbuscular mycorrhizal fungus: a mechanism of habitat modification? Soil Biol. Biochem., 34: 1371-1374.

Rillig MC, Ramsey PW, Morris S, Paul EA. 2003. Glomalin, an arbuscular-mycorrhizal fungal soil protein, responds to landuse change. Plant Soil, 253: 293-299. 
Rillig MC. 2004. Arbuscular mycorrhizae, glomalin and soil aggregation. Canadian J. Soil Sci., 84: 355 - 363.

Rillig, MC, Mummey DL. 2006. Mycorrhizas and soil structure. New Phytologist, 171: 41 - 53.

Rillig MC, Caldwell BA, Wosten HAB, Sollins P. 2007. Role of proteins in soil carbon and nitrogen storage: controls on persistence. Biogeochemistry, 85: 25-44.

Rogers HH, Runion GB, Krupa SV. 1994. Plant responses to atmospheric $\mathrm{CO}_{2}$ enrichment with emphasis on roots and the rhizosphere. Environ. Pollut., 83(1-2): 155-189.

Sharifi Z, Azadi N, Rahimi S, Certini G. 2018. The response of glomalin-related soil proteins to fire or tillage. Geoderma, 329: 65-72.

Steinberg PD, Rillig MC. 2003. Differential decomposition of arbuscular mycorrhizal fungal hyphae and glomalin. Soil Biol. Biochem., 35: 191-194.

Treseder KK, Allen MF. 2000. Mycorrhizal fungi have a potential role in soil carbon storage under elevated $\mathrm{CO}_{2}$ and nitrogen deposition. New Phytology, 147: 189-200.

Treseder KK, Mack MC, Cross A. 2004. Relationships among fires, fungi, and soil dynamics in Alaskan boreal forests. Ecol. Applications, 14: 1826-1838.

Treseder KK, Turner KM. 2007. Glomalin in ecosystems. Soil Sci. Soc. Am. J. 71: 1257-1266.

Vodnik D, Maeek I., Peli E, Videmsek U, Tuba Z. 2008. Elevated $\mathrm{CO}_{2}$ affects the content of glomalin related soil protein inxeric temperate loess and temperate semi-desert sand grasslands. Community Ecology, 9( 1): 161-166.

Wang Q, Wang WJ, He XY, Zhang WT, Song KS, Han SJ. 2015. Role and variation of the amount and composition of glomalin in soil properties in farmland and adjacent plantations with reference to a primary forest in North-Eastern China. PLoS ONE, 10(10): e0139623.

Wang W, Zhong Z, Wang Q, Wang H, Fu Y, He X. 2017. Carbon, nutrients in deeper soils, and differently associated with climates and soil properties in vertical profiles. Scientific Reports, 7: 1-13.

Wang Q, Lu H, Chen J, Hong H, Liu J, Li J, Yan C. 2018. Spatial distribution of glomalin-related soil protein and its relationship with sediment carbon sequestration across a mangrove forest. Sci. Total Environ., 613: 548-556.
Wang Q, Wang W, Zhong Z, Wang H, Fu Y. 2020. Variation in glomalin in soil profiles and its association with climatic conditions, shelterbelt characteristics, and soil properties in poplar shelterbelts of Northeast China. J. Forest. Res., 31: 279-290.

Wright SF, Franke-Snyder M, Morton JB, Upadhyaya A. 1996. Time course study and partial characterization of a protein on hyphae of arbuscular mycorrhizal fungi during active colonization of roots Plant Soil, 181: 193-203.

Wright SF, Upadhyaya A. 1998. A survey of soils for aggregate stability and glomalin, a glycoprotein produced by hyphae of arbuscular mycorrhizal fungi. Plant Soil, 198: 97-107.

Wright SF, Upadhyaya A. 1999. Quantification of arbuscular mycorrhizal activity by the glomalin concentration on hyphae. Mycorrhiza, 8: 283-285.

Wright S, Anderson RL. 2000. Aggregate stability and glomalin in alternative crop rotations for the central Great Plains. Biol. Fertility Soils, 31: 249-253.

Wright SF, Rillig MC, Nichols KA. 2000. Glomalin: a soil protein important in carbon sequestration. Proceedings American Chemical Society Annu. Meet. Symp., 45: 721725 .

Wright SF, Nichols KA. 2002. Glomalin: Hiding place for a third of the world's stored soil carbon. Agril. Res. Magazine, 50(9): 4-7.

Wuest SB, Caesar-TonThat TC, Wright SF, Williams JD. 2005. Organic matter addition, $\mathrm{N}$, and residue burning effects on infiltration, biological, and physical properties of an intensively tilled silt-loam soil. Soil Tillage Res. 84: 154167.

Zhang J, Tang X, He X, Liu J. 2016. Glomalin-related soil protein responses to elevated $\mathrm{CO} 2$ and nitrogen addition in a subtropical forest: Potential consequences for soil carbon accumulation. Soil Biology \& Biochemistry, 83: 142-149.

Zhang J, Tang X, Zhong S, Yin G, Gao Y, He X. 2016. Recalcitrant carbon components in glomalin-related soil protein facilitate soil organic carbon preservation in tropical forests. Scientific Reports, 7(1): 1-9.

Zhu, YG, Miller, RM. 2003. Carbon cycling by arbuscular mycorrhizal fungi in soil- plant systems. Trends Plant Sci., 8(9): 407-409. 